\title{
STUDI KELAYAKAN INVESTASI PEMBANGUNAN PERKEBUNAN KARET DI SUMATERA SELATAN
}

\author{
Feasibility Study of Investment of Rubber Plantation Development in South Sumatra \\ Lina Fatayati SYARIFA \\ Balai Penelitian Sembawa, Pusat Penelitian Karet \\ Jalan Raya Palembang - P. Balai KM 29, PO BOX 1127 Palembang 30001 \\ Email : lina_fsy@yahoo.com
}

Diterima : 3 Desember 2013 / Direvisi : 17 Februari 2014 / Disetujui : 23 Mei 2014

\begin{abstract}
Interested in the present rubber price, many agribusiness companies have started to develop rubber plantations. This opportunity has been taken by state and private owned plantations. Socio economic feasibility study is needed before the opening of the rubber development project. The aim of this paper was to analyze investment feasibility of rubber plantation development in South Sumatra. This research used a case study method in South Sumatra by collecting primary data from the experimental garden of Sembawa Research Centre and secondary data with some assumptions. Feasibility analysis used indicators of Net Present Value (NPV), Internal Rate of Return (IRR), Benefit Cost Ratio (B/C ratio), and Payback Period. The analysis results showed that investment of rubber plantation development in South Sumatra with an area of 3000 ha with land suitability of S3, rubber price of US \$2.55 per $\mathrm{kg}$, and discount factor of $11 \%$ were feasible with NPV of $R p .209 .4$ billion; IRR of $16 \%$; $B / C$ ratio of 1.43 ; and payback period of 11 years 10 months. Similarly, in the conditions where the natural rubber price decreased by 5\% up to us $\$ 2.4$ per $\mathrm{kg}$ and production costs increased by 5\%, the project was proved to be feasible to conduct.
\end{abstract}

Keywords: Feasibility, investment, rubber plantation, development

\section{Abstrak}

Dengan harga karet seperti saat ini, banyak pelaku agribisnis yang tertarik untuk mengembangkan perkebunan karet. Peluang ini dimanfaatkan oleh perusahaan-perusahaan perkebunan baik milik negara (BUMN) maupun swasta dengan mencari lahan untuk membangun atau memperluas perkebunan karet. Studi kelayakan sosial ekonomi merupakan salah satu studi yang perlu dilakukan sebelum proyek pembangunan perkebunan karet dilaksanakan oleh suatu perusahaan. Artikel ini ditujukan untuk menganalisis kelayakan investasi pembangunan perkebunan karet. Penelitian menggunakan metode studi kasus di Sumatera Selatan dengan mengumpulkan data primer dari Kebun Percobaan Balai Penelitian Sembawa dan data sekunder dengan beberapa asumsi. Analisis kelayakan menggunakan indikator NPV, IRR, B/C ratio, dan Payback Period. Hasil analisis menunjukkan bahwa secara finansial investasi pembangunan kebun karet di Sumatera Selatan dengan luas 3000 ha dengan kesesuaian lahan S3 dan harga US \$2,55 per kg serta tingkat diskonto $11 \%$ layak untuk dilaksanakan dengan nilai $\mathrm{Net}$ Present Value (NPV) Rp. 209,4 milyar; IRR 16\%; B/C ratio 1,43; dan Payback Period 11 tahun 10 bulan. Demikian juga pada kondisi yang kurang menguntungkan dimana harga karet alam turun hingga US \$2,4 per $\mathrm{kg}$ dan kenaikan biaya produksi sebesar 5\% dari kondisi normal yang direncanakan, proyek ini masih layak dilaksanakan.

Kata kunci: Kelayakan, investasi, perkebunan karet, pengembangan

\section{PENDAHULUAN}

Konsumsi karet alam dunia dalam tiga dekade terakhir (1980-2012) meningkat secara drastis, walaupun terjadi resesi ekonomi dunia pada awal tahun 1980-an dan krisis ekonomi Asia pada tahun 1997 / 1998 serta resesi ekonomi di Amerika Serikat yang berdampak terhadap krisis global pada akhir tahun 2008 hingga pertengahan tahun 2009. Gambaran keseluruhan mengenai perkembangan konsumsi karet alam dunia untuk tahun 1980-2012 dapat dilihat pada Tabel 1.

Konsumsi karet alam dunia dalam jangka panjang diperkirakan akan terus meningkat sejalan dengan pertumbuhan perekonomian dunia dan meningkatnya 
Tabel 1. Perkembangan konsumsi karet alam dunia, 1980-2012

Table 1. Development of world natural rubber consumption, 1980-2012

\begin{tabular}{ccc}
\hline \multirow{2}{*}{$\begin{array}{c}\text { Tahun } \\
\text { Year }\end{array}$} & \multicolumn{2}{c}{$\begin{array}{c}\text { Konsumsi karet alam total } \\
\text { Total of natural rubber consumption }\end{array}$} \\
\cline { 2 - 3 } & $\begin{array}{c}\text { Volume } \\
\text { ('000 ton) }\end{array}$ & $\begin{array}{c}\text { Pertumbuhan / tahun } \\
\text { Growth/year } \\
(\%)\end{array}$ \\
\hline 1980 & 3.770 & \\
1990 & 5.180 & 6,30 \\
2000 & 7.340 & 6,90 \\
2005 & 8.745 & 3,49 \\
2010 & 10.764 & 4,14 \\
2011 & 10.998 & 2,15 \\
2012 & 11.033 & 0,32 \\
\hline
\end{tabular}

Sumber (Source): Anwar, 2005 dan IRSG, 2013.

standar hidup manusia. Pertumbuhan perekonomian dunia yang pesat di China, India, Korea Selatan dan Brazil pada sepuluh tahun terakhir, telah memberi dampak pertumbuhan permintaan karet alam yang cukup tinggi. Smit (2003) memprediksi bahwa pertumbuhan konsumsi karet alam ke depan akan terus meningkat melampaui tingkat pertumbuhan produksi. Diperkirakan permintaan karet alam pada tahun 2035 akan mencapai sekitar 15 juta ton, sedangkan pertumbuhan produksi akan stabil pada sekitar $2 \%$ per tahun, sehingga produksi karet alam dunia tahun 2035 hanya mencapai sekitar 13,6 juta ton. Hal ini berarti akan terjadi kekurangan pasokan karet alam untuk memenuhi kebutuhan konsumsi dunia.

Indonesia memiliki peluang untuk menjadi produsen terbesar dunia. Indonesia memiliki keunggulan komparatif dan kompetitif yang lebih baik dibandingkan dengan negara-negara pesaing seperti Thailand dan Malaysia, karena masih memiliki lahan yang lebih luas dan tenaga kerja yang cukup untuk mendukung pembangunan kebun karet. Dengan harga karet seperti saat ini, banyak pelaku agribisnis yang tertarik untuk mengembangkan perkebunan karet. Peluang ini dimanfaatkan oleh perusahaanperusahaan perkebunan baik milik negara (BUMN) maupun swasta dengan mencari lahan untuk memperluas perkebunan karet.
Untuk mengembangkan karet perlu dipertimbangkan berbagai faktor secara matang, tidak hanya faktor kesesuaian lahan dan agroklimat saja tetapi juga faktor sosial ekonomi. Studi kelayakan sosial ekonomi merupakan salah satu studi yang perlu dilakukan sebelum proyek pembangunan karet dilaksanakan oleh suatu perusahaan. Studi kelayakan sosial ekonomi ditujukan pada kondisi calon pengelola lahan karet di lapangan dan masyarakat di sekitar areal konsesi dengan menggali informasi mengenai: kondisi umum wilayah, ketersediaan pra/sarana dan kelembagaan sosial ekonomi, kondisi demografi dan ketersediaan tenaga kerja lokal, dan tanggapan masyarakat terhadap rencana pembangunan perkebunan karet. Selanjutnya dilakukan pengkajian aspek ekonomi yang didasari aspek teknis pada areal yang akan digunakan untuk perkebunan karet. Dari aspek ekonomi akan dilakukan analisis investasi yang memberikan kesimpulan mengenai layak atau tidaknya usaha pembangunan kebun karet di areal tertentu serta memberikan gambaran tingkat keuntungan atau kerugian pengusahaan kebun karet dalam siklus umur ekonomi selama 25 tahun (30 tahun umur tanaman). Artikel ditujukan untuk menganalisis kelayakan investasi pembangunan perkebunan karet di Sumatera Selatan. Hasil analisis ditujukan untuk memberikan gambaran umum mengenai kelayakan investasi bagi stakeholder yang berencana membangun perkebunan karet. 


\section{BAHAN DAN METODE}

Penelitian dilakukan pada bulan Mei 2013 menggunakan metode studi kasus di Sumatera Selatan dengan mengumpulkan data primer dari Kebun Percobaan Balai Penelitian Sembawa yang meliputi norma biaya pembangunan kebun karet, pemeliharaan dan pemanenan. Selain itu dilakukan juga pengambilan data sekunder dan penentuan beberapa asumsi. Analisis kelayakan investasi menggunakan beberapa metode sebagai indikator kelayakan (Gittinger, 1986) antara lain:

1. Nilai Sekarang atau Net Present Value (NPV) Kriteria kelayakannya adalah apabila NPV $>0$

2. Rasio Manfaat dan Biaya atau Benefit Cost Ratio Analysis (B/C Ratio) Kriteria kelayakannya adalah bila $\mathrm{B} / \mathrm{C}$ ratio $>1$

3. Tingkat Suku Bunga Pengembalian Modal atau Internal Rate of Return (IRR) Kriteria kelayakannya adalah apabila IRR > suku bunga bank yang berlaku umum (Minimum Attractive Rate of Return/MAARR)

4. Periode Pengembalian Modal (Payback Period Analysis) Kriteria penilaiannya adalah semakin singkat pengembalian investasi akan semakin baik.

Selanjutnya dilakukan analisis sensitivitas untuk menguji tingkat kelayakan jika terjadi gejolak ekonomi akibat fluktuasi dan dinamika harga. Analisis sensitivitas pembangunan kebun karet dilakukan terhadap variabel yang diduga memiliki pengaruh secara sensitif terhadap nilai indikator-indikator kelayakan investasi antara lain harga karet alam dan biaya produksi. Dalam analisis sensitivitas dibuat dua skenario. Skenario pertama adalah harga karet turun 5\% per kg dengan faktor lainnya tetap. Skenario kedua adalah kenaikan biaya produksi sebesar 5\% dari kondisi normal, dan faktor lainnya tetap.

Analisis kelayakan menggunakan beberapa asumsi sebagai berikut:

1. Tahun awal proyek adalah 2014

2. Luasan efektif yang ditanami karet adalah 3000 ha yang dilakukan secara bertahap dengan tiga tahapan, yaitu tahun tanam 2014 seluas 500 ha, tahun tanam 2015 seluas 1000 ha, dan tahun tanam 2016 seluas 1500 ha.

3. Umur ekonomi tanaman adalah 30 tahun, yaitu 5 tahun masa tanaman belum menghasikan (TBM) dan 25 tahun masa tanaman menghasilkan (TM).

4. Pembiayaan proyek menggunakan dana perusahaan sendiri.

5. Biaya pemeliharaan aktiva tetap kebun per tahun ditetapkan sebesar 5\% dari aset non tanaman.

6. Biaya umum kebun per tahun adalah $5 \%$ dari biaya investasi.

7. Penghitungan depresiasi dengan menggunakan metode garis lurus (straight line), dengan penyusutan bangunan selama 20 tahun, dan kendaraan serta alat kantor selama 10 tahun.

8. Tenaga penyadap tidak berdomisili di dalam lokasi kebun.

9. Biaya pajak bumi dan bangunan (PBB) per tahun dihitung berdasarkan SIT (Standar Investasi Tanaman) 2014, dengan menggunakan Indeks Biaya Tanaman (IBT) dan Satuan Biaya Pembangunan Kebun (SBPK) sesuai dengan peraturan untuk Wilayah Sumatera Selatan, yang nilainya sesuai dengan peraturan Dirjen Pajak No SE81/PJ/2008.

10. Pajak penghasilan perusahaan sebesar $25 \%$ per tahun dari laba sebelum pajak (sesuai UU No. 36 Tahun 2008 tentang Pajak Penghasilan (PPH).

11. Harga jual produk yang dihasilkan kebun adalah 95\% dari harga FOB SIR 20 yang dalam analisis ini ditetapkan secara konservatif yakni sebesar US\$ 2,55 per kg (harga rata-rata yang terjadi pada bulan Mei 2013) dengan nilai tukar Rp 10.000 per US\$.

12. Harga jual kayu karet $\mathrm{Rp} 300.000,-/ \mathrm{m}^{3}$, dengan asumsi 1 ha $=100 \mathrm{~m}^{3}$.

13. Discount factor ditetapkan sebesar $11 \%$.

\section{HASIL DAN PEMBAHASAN}

\section{Kebutuhan Tenaga Kerja untuk Perkebunan Karet}

Pembangunan perkebunan karet akan berdampak pada peningkatan kebutuhan tenaga kerja di desa. Perkebunan karet sangat banyak membutuhkan tenaga kerja terutama untuk kegiatan penyadapan. Jumlah tenaga kerja penyadap yang dibutuhkan bagi sebuah unit pembangunan perkebunan karet dapat dilihat pada Tabel 2. Jumlah tenaga kerja 
penyadap tergantung pada sistem eksploitasi/penyadapan yang digunakan. Oleh karena itu, bagi perusahaan yang menerapkan sistem eksploitasi $\mathrm{S} / 2 \mathrm{D} / 2$ (tanpa stimulan), jumlah tenaga kerja penyadap yang akan dibutuhkan bagi suatu unit pembangunan perkebunan (dengan lahan yang efektif seluas 3000 ha) sebanyak 1500 orang. Sementara untuk sistem eksploitasi S/2 D/3 (dengan stimulan), akan dibutuhkan jumlah tenaga kerja penyadap sebanyak 1000 orang. Pada wilayah dengan tenaga kerja terbatas, kebutuhan tenaga penyadap dapat dikurangi apabila menggunakan stimulan dengan sistem eksploitasi S/2 D/4.

Kebutuhan tenaga kerja tersebut dapat dipenuhi oleh tenaga kerja lokal atau mendatangkan tenaga kerja dari luar. Oleh karena itu, informasi mengenai ketersediaan jumlah tenaga kerja serta tingkat pengetahuan dan keterampilan tenaga kerja di desa-desa sekitar areal konsesi sangat diperlukan apabila perusahaan ingin merekrut tenaga kerja lokal. Mengenai penggunaan tenaga kerja dari luar daerah, kajian penerimaan atau resistensi masyarakat lokal terhadap penduduk/tenaga kerja pendatang sangat diperlukan untuk mengetahui apakah masyarakat lokal bisa menerima masyarakat/tenaga kerja dari luar dengan baik. Hal ini bertujuan untuk menghindari timbulnya potensi konflik yang akan terjadi antara masyarakat/tenaga kerja lokal dengan masyarakat/tenaga kerja pendatang (Wijaya et al., 2012; Syarifa, 2013).

\section{Biaya Investasi}

Berdasarkan asumsi: (1) luasan efektif yang ditanami karet adalah 3000 ha yang dilakukan secara bertahap dengan 3 tahapan, yaitu tahun tanam 2014 seluas 500 ha, tahun tanam 2015 seluas 1000 ha, dan tahun tanam 2016 seluas 1500 ha, (2) dengan standar input yang digunakan, diperkirakan tanaman karet yang diusahakan mampu berproduksi pada saat tanaman karet menginjak umur enam tahun, sehingga masa investasi kebun adalah dari TBM-0 hingga TBM-5 untuk tiap tahapan, maka total biaya investasi kebun dari TBM-0 hingga TBM-5 adalah sekitar Rp. 48,6 juta/hektar. Jika dirinci per komponen maka struktur biaya investasi kebun adalah seperti terlihat pada Tabel 3. Total biaya investasi yang diperlukan untuk membangun kebun karet seluas 3000 ha adalah Rp. 145,7 Milyar.

\section{Produktivitas Kebun}

Potensi lahan untuk pengembangan tanaman karet dapat ditentukan jika keadaan tanah dan iklim diketahui terlebih dahulu. Kondisi tanah dan iklim tersebut dihubungkan terhadap sifat-sifat yang dikehendaki tanaman karet. Hubungan tersebut menghasilkan suatu sistem klasifikasi kesesuaian lahan yang tujuannya untuk menilai seberapa jauh tingkat kesesuaian suatu lahan terhadap tanaman karet (Tabel 4). Melalui penerapan teknologi anjuran lembaga penelitian secara konsisten termasuk penggunaan klon yang sesuai dengan kondisi lahan dan agroklimat, diproyeksikan tingkat produktivitas kebun mencapai maksimal. Diasumsikan lahan perkebunan di Sumatera Selatan termasuk dalam kesesuaian kelas 3 untuk tanaman karet. Dengan kondisi lahan seperti dijelaskan maka produktivitas tanaman karet di kebun diperkirakan rata-rata dalam satu siklus tanam sebesar 1,652 $\mathrm{kg} / \mathrm{ha} /$ tahun.

Tabel 2. Kebutuhan jumlah tenaga kerja penyadap per unit pembangunan kebun karet Table 2. Number of rubber tappers needed for every unit of rubber plantation development

\begin{tabular}{lcc}
\hline Sistem penyadapan & $\begin{array}{c}\text { Kebutuhan jumlah tenaga kerja penyadap } \\
\text { (orang) }\end{array}$ \\
& Namping system & \multicolumn{2}{c}{$\begin{array}{c}\text { Nubber tappers needed } \\
\text { (person) }\end{array}$} \\
\cline { 2 - 3 } & Per Ha & Per 3000 Ha \\
\hline $\mathrm{S} / 2 \mathrm{D} / 2$ & $1 / 2$ & 1500 \\
$\mathrm{~S} / 2 \mathrm{D} / 3$ & $1 / 3$ & 1000 \\
$\mathrm{~S} / 2 \mathrm{D} / 4$ & $1 / 4$ & 750 \\
\hline
\end{tabular}


Tabel 3. Struktur biaya investasi per hektar

Tabel 3. Invesment cost per hectare

\begin{tabular}{|c|c|c|c|c|c|c|c|c|}
\hline \multirow[t]{2}{*}{ No } & \multirow[t]{2}{*}{$\begin{array}{l}\text { Investasi } \\
\text { Investment }\end{array}$} & \multicolumn{7}{|c|}{$\begin{array}{c}\text { Biaya/Ha pada tahun ke- } \\
\text { Cost/Ha in year } \\
(\mathrm{Rp} 000,-)\end{array}$} \\
\hline & & 0 & 1 & 2 & 3 & 4 & 5 & Total \\
\hline 1 & $\begin{array}{l}\text { Tanaman } \\
\text { Bahan, alat dan TK KHL }\end{array}$ & 19.538 & 5.103 & 4.616 & 4.942 & 5.060 & 4.821 & 44.080 \\
\hline 2 & Bangunan & 894 & 694 & 825 & 0 & 0 & 1.026 & 3.440 \\
\hline 3 & $\begin{array}{l}\text { Kendaraan dan } \\
\text { peralatan kantor }\end{array}$ & 560 & 213 & 287 & 0 & 0 & 0 & 1.060 \\
\hline & Total biaya investasi & 20.992 & 6.010 & 5.728 & 4.942 & 5.060 & 5.847 & 48.580 \\
\hline
\end{tabular}

Tabel 4. Kelas kesesuaian lahan berdasarkan tanah dan iklim

Table 4. Class ofland suitability based on land and climate conditions

\begin{tabular}{lcccc}
\hline \multirow{2}{*}{ Iklim } & \multicolumn{4}{c}{ Tanah } \\
\cline { 2 - 5 } Climate & Soil & \\
& Very appropriate & Cukup sesuai & Kurang sesuai & Tidak sesuai \\
& (S1) & Less appropriate & Less apriate & Not appropriate \\
& Sangat sesuai & Sangat sesuai & Cukup sesuai & Kurang sesuai \\
& Cukup sesuai & Cukup sesuai & Cukup sesuai & Kurang sesuai \\
\hline Sangat sesuai (S1) & Kurang sesuai & Kurang sesuai & Kurang sesuai & Tidak sesuai \\
Cukup sesuai (S2) & Tidak sesuai & Tidak sesuai & Tidak sesuai & Tidak sesuai \\
Kurang sesuai (S3) & & & & \\
Tidak sesuai (TS) & & &
\end{tabular}

\section{Neraca Laba Rugi Pembangunan Kebun}

Tabel 5 menyajikan perhitungan laba rugi kebun per satu siklus tanaman yang dimulai dari masa investasi hingga masa penebangan (30 tahun). Dari Tabel 5 disimpulkan bahwa pada akhir siklus usaha, pembangunan kebun karet menghasilkan laba bersih (setelah dipotong pajak) sebesar Rp 1,26 trilyun, sedangkan perhitungan laba rugi tahunan dirinci pada Tabel 6.

Tabel 5. Perhitungan laba rugi satu siklus usaha karet

Table 5. Profil and loss calculation of one cycle rubber industry

\begin{tabular}{lr}
\hline Penerimaan : & Nilai (Rp. 000) \\
Penjualan karet & 3.000 .968 .775 \\
Penjualan kayu karet & 90.000 .000 \\
\hline Total Penerimaan & 3.090 .968 .775 \\
\hline Biaya : & \\
Pemeliharaan tanaman & 354.690 .000 \\
Panen dan Transportasi & 624.866 .261 \\
Pemeliharaan aktiva tetap & 20.915 .200 \\
PBB & 10.172 .002 \\
Gaji dan Tunjangan & 162.329 .700 \\
Biaya umum & 219.271 .105 \\
Penyusutan & 11.711 .050 \\
Asuransi & 1.146 .865 \\
\hline Total Biaya & 1.405 .102 .183 \\
\hline Laba Operasi (sebelum pajak) & 1.685 .866 .592 \\
Pajak & 425.057 .519 \\
Laba Bersih (setelah dipotong pajak) & 1.260 .809 .074 \\
\hline
\end{tabular}




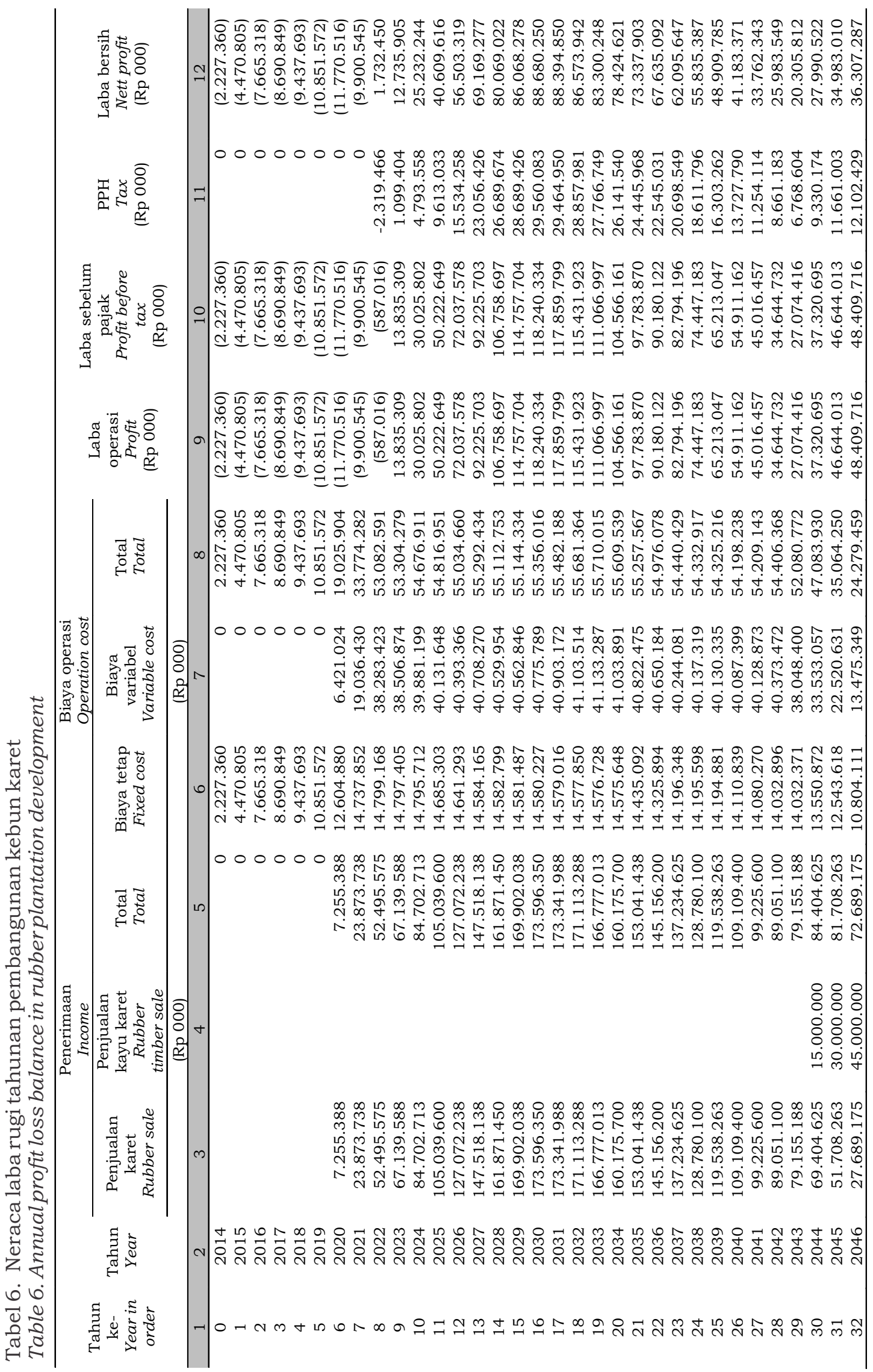




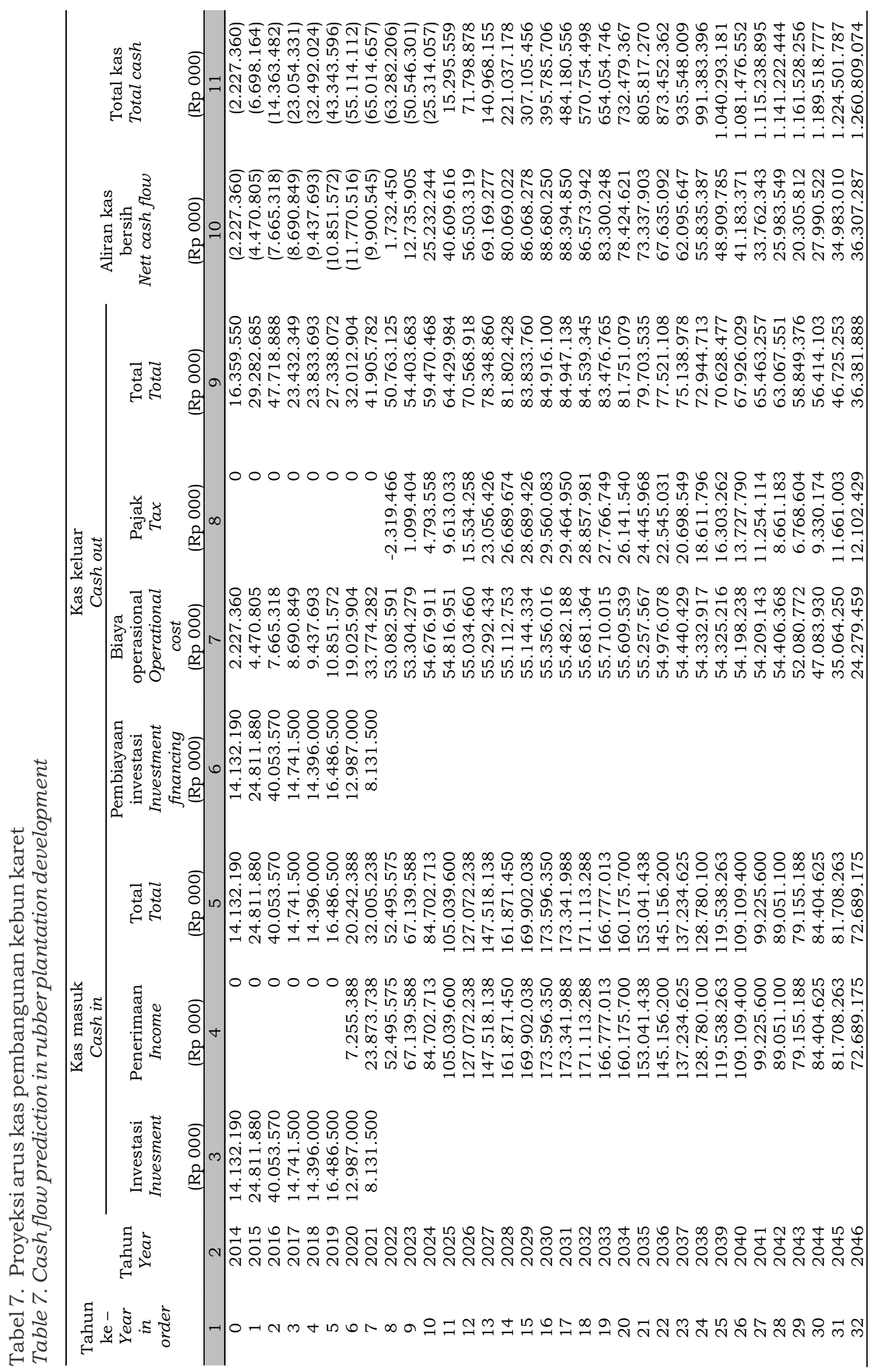




\section{Proyeksi Arus Kas}

Proyeksi arus kas menampilkan komponen penerimaan dan pengeluaran selama periode analisis. Penerimaan dalam arus kas terdiri atas nilai penjualan produksi karet dan nilai penjualan kayu karet pada masa akhir umur ekonomi tanaman. Sementara pengeluaran dalam arus kas terdiri atas biaya investasi, bunga pinjaman dan biaya produksi (termasuk di dalamnya adalah komponen biaya penyusutan dan pemeliharaan aset tetap serta asuransi). Proyeksi arus kas disajikan pada Tabel 7.

\section{Kelayakan Investasi}

Tabel 8 menyajikan informasi hasil analisis kelayakan menggunakan indikator NPV, IRR, B/C ratio, dan Payback Period. Seperti terlihat pada Tabel 8, semua indikator kelayakan memperlihatkan bahwa pembangunan kebun karet layak untuk dilaksanakan. Kelayakan investasi pembangunan kebun karet menghasilkan nilai NPV positif (df 11\%) sebesar Rp. 209,4 milyar, nilai IRR sebesar 16\%, lebih tinggi dari tingkat discount factor yang ditetapkan sebesar $11 \%$, dan nilai $\mathrm{B} / \mathrm{C}$ ratio sebesar
1,43, sedangkan tingkat pengembalian investasi dapat diperoleh pada umur 11 tahun 10 bulan.

\section{Analisis Sensitivitas}

Dalam analisis sensitivitas dibuat 2 skenario. Skenario pertama adalah harga karet turun $5 \%$ per kg sehingga menjadi US \$ 2,4 per $\mathrm{kg}$ dengan faktor lainnya tetap. Skenario kedua adalah kenaikan biaya $5 \%$ dari kondisi normal, dengan faktor lainnya tetap. Tabel 9 menyajikan hasil analisis sensitivitas dengan dua skenario di atas. Dengan skenario tersebut, pembangunan kebun karet relatif sensitif terhadap penurunan harga karet alam dan kenaikan biaya produksi dimana terjadi penurunan nilai terhadap NPV, IRR, dan B/C Ratio, serta lamanya masa pengembalian modal. Namun demikian, pada kondisi yang kurang menguntungkan dimana harga karet alam turun hingga US\$ 2,4 per $\mathrm{kg}$ dan kenaikan biaya produksi sebesar $5 \%$ dari kondisi normal yang direncanakan, proyek ini masih layak dilaksanakan. Hal ini sejalan dengan penelitian-penelitian sebelumnya (Wijaya, 2012; Istianto et al., 2012; Susetyo et al., 2012; Syarifa, 2013).

Tabel 8. Nilai indikator kelayakan finansial pembangunan kebun karet Table 8. Indicator value of financial feasibility in rubber plantation development

\begin{tabular}{clr}
\hline No & \multicolumn{1}{c}{$\begin{array}{c}\text { Kriteria kelayakan investasi } \\
\text { Investment feasibility criterias }\end{array}$} & \multicolumn{1}{c}{ Nilai } \\
\hline 1 & Net Present Value-NPV (df = 11\%) (Rp. 000) \\
2 & Internal Rate of Return - IRR (\%) & 209.400 .910 \\
3 & Net Benefit Cost Ratio - B/C ratio & 16 \\
4 & Payback Period - PBP (tahun) & 11 tahun 10 bulan \\
\hline $\mathrm{df}=$ Discount Factor
\end{tabular}

Tabe1 9. Analisis sensitivitas proyek pembangunan kebun karet Table 9. Sensitivity analysis of rubber plantation development project

\begin{tabular}{|c|c|c|c|c|}
\hline \multirow{3}{*}{ No } & \multirow{3}{*}{$\begin{array}{l}\text { Kriteria kelayakan investasi } \\
\text { Invesment feasibility criterias }\end{array}$} & \multicolumn{3}{|c|}{$\begin{array}{l}\text { Nilai kelayakan dengan skenario } \\
\text { Feasibility value by scenario }\end{array}$} \\
\hline & & $\begin{array}{c}\text { Harga karet alam } \\
\text { US } \$ 2,55 / \mathrm{kg} \text { dan } \\
\text { produktivitas } 100 \%\end{array}$ & $\begin{array}{l}\text { Penurunan harga } \\
\text { karet alam menjadi } \\
\text { US } \$ 2,4 / \mathrm{kg}\end{array}$ & $\begin{array}{l}\text { Kenaikan } \\
\text { biaya } 5 \%\end{array}$ \\
\hline & & $\begin{array}{c}\text { Rubber price US } \$ \\
2.55 / \mathrm{kg} \text { and } \\
\text { productivity } 100 \%\end{array}$ & $\begin{array}{l}\text { Decrease of rubber } \\
\text { price by US } \$ 2.4 / \mathrm{kg}\end{array}$ & $\begin{array}{l}\text { Increase of } \\
\text { cost by 5\% }\end{array}$ \\
\hline 1 & $\begin{array}{l}\text { Net Present Value-NPV } \\
(\mathrm{df}=11 \%) \quad(\text { Rp. } 000)\end{array}$ & 209.400 .910 & 187.299 .263 & $\begin{array}{r}197.556 .2 \\
94\end{array}$ \\
\hline 2 & Internal Rate of Return - IRR (\%) & 16 & 15 & 15 \\
\hline 3 & Net Benefit Cost Ratio - B/C ratio & 1,43 & 1,39 & 1.40 \\
\hline 4 & Payback Period - PBP (tahun) & 11 tahun 10 bulan & 12 tahun & $\begin{array}{l}11 \text { tahun } \\
11 \text { bulan }\end{array}$ \\
\hline
\end{tabular}




\section{KESIMPULAN DAN SARAN}

Secara finansial investasi pembangunan kebun karet di Sumatera Selatan seluas 3000 ha dengan kesesuaian lahan S3 dengan tahun awal 2014 layak untuk dilaksanakan dengan nilai Net Present Value (NPV) Rp 209,4 milyar; IRR 16\%; B/C ratio 1,43; dan Payback Period 11 tahun 10 bulan. Demikian juga pada kondisi yang kurang menguntungkan dimana harga karet alam turun hingga US\$ 2,4 per $\mathrm{kg}$ dan kenaikan biaya produksi sebesar 5\% dari kondisi normal yang direncanakan, proyek ini masih layak dilaksanakan. Hasil analisis kelayakan sosial ekonomi bagi ekspansi perkebunan karet menjadi informasi/kajian yang sangat berguna bagi suatu perusahaan. Hal ini digunakan sebagai bahan pertimbangan sebelum memutuskan untuk melakukan take over terhadap lahan maupun untuk membangun kebun karet di areal konsesi yang dimilikinya. Dengan demikian pelaksanaan pembangunan kebun karet dapat berjalan lancar dan memberikan keuntungan yang optimal bagi perusahaan.

\section{DAFTAR PUSTAKA}

Anwar, C. 2006. Perkembangan Pasar dan Prospek Agribisnis Karet di Indonesia. Prosiding Lokakarya Nasioanl Budidaya Tanaman Karet. Medan, 4-6 September. Pusat Penelitian Karet.: 10 $-23$

Gittinger, J. P. 1986. Analisa Ekonomi Proyek-proyek Pertanian. Edisi Kedua. UI-Press, Jakarta.
International Rubber Study Group (IRSG). 2013. Statistical Summary of World Rubber Situation. International Rubber Study Group, Singapore.

Smit, H. P. 2003. The World Tyre and Rubber Industry and the China Factor: Some Scenario for the Future. Jakarta.

Wijaya, Thomas. 2008. Kesesuaian Tanah dan Iklim Untuk Tanaman Karet. Warta Perkaretan 27(2): 34 - 44.

Wijaya, T., J. Saputra, L. F, Syarifa, D. S, Agustina, dan N. A, Kinasih. 2012. Studi Kelayakan Pembangunan HTI Karet PT. Pancaran Wananusa di Kabupaten Lamandau Provinsi Kalimantan Tengah. Laporan Pelayanan. Pusat Penelitian Karet, Bogor.

Istianto, S. R. Ahmad, I. Fathurrohman, L. F. Syarifa, dan N. A. Kinasih. 2012. Studi Kesesuaian Lahan dan Sosial Ekonomi untuk Pengembangan Karet di Kabupaten Bangka, Propinsi Bangka Belitung. Laporan Pelayanan. Pusat Penelitian Karet, Bogor.

Susetyo, I. S. R. Ahmad, T. Widyasari. dan L. F. Syarifa. 2012. Studi Kesesuaian Lahan dan Sosial Ekonomi untuk Pengembangan Karet Perum Perhutani III, Provinsi Jawa Barat. Laporan Pelayanan. Balai Penelitian Getas, Salatiga.

Syarifa, L. F. 2013. Ekspansi Lahan Perlu Studi Kelayakan. Hevea V (1) : 14-18 